\title{
Comparative Study of Certain Biochemical Profile of Broiler and Indigenous Chicken of Assam
}

\author{
Kalita $\mathrm{DJ}^{1 *}$, Sultana $\mathrm{R}^{2}$, Roy $\mathrm{MN}^{3}$ and Bharali $\mathrm{K}^{3}$ \\ ${ }^{1}$ Department of Veterinary Biochemistry, India \\ ${ }^{2}$ Veterinary Officer, India \\ ${ }^{3}$ Department of Extension Education, India
}

*Corresponding author: Kalita DJ, Professor, Department of Veterinary Biochemistry, College of Veterinary Science, , Khanapara, Guwahati, Assam, India

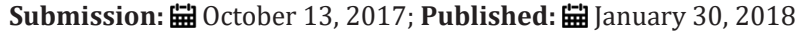

\begin{abstract}
Biochemical profiles of chickens provide valuable information for evaluation of health status and are reliable indicator of health. The sole purpose of the present study was to determine and compare the base line value of certain serum biochemical profile of broiler and indigenous chickens of Assam. Blood samples from apparently healthy, 20 each broiler (cob 400 strain) and indigenous chickens of Assam weighing between 1.5-2.0Kg were collected from local butchers at the time of slaughter, early in the morning in three different days from Guwahati city and average values for each parameters were taken. Sodium fluoride was used as anticoagulant for estimation of blood glucose and other parameters namely total protein, albumin, globulin, cholesterol, urea, uric acid and creatinine was estimated in serum following standard protocol. Data generated from the experiment were analyzed statistically using SAS Enterprise Guide (Version 4.2). From the present study, it was concluded that certain parameters like glucose, total protein, albumin, globulin, urea, uric acid and cholesterol significantly $(\mathrm{P}<0.05)$ varied between broiler and indigenous chickens of Assam. However, the concentration of creatinine did not differed between the two groups.
\end{abstract}

Keywords: Biochemical profile, Broiler, Indigenous chicken

\section{Introduction}

The indigenous chickens (Gallus domesticus) have been reared in rural villages in Assam for a long time. These birds are important to low-income people who live in the rural part of the state. India produces 4.2 millions tones of meat annually but the availability of animal protein is only $8.3 \mathrm{gm}$ per head per day [1,2], against a minimum requirement of $15 \mathrm{~g}$ per head per day as per recommendation of Indian Council of Medical Research. To reduce the gap between the demand and availability, new broiler strains with high genetic potential for growth and indigenous chicken with low maintenance cost has gaining popularity across the country [3]. Household poultry has been also included in the FAO special programme for food security [4]. Serum biochemical profiles of chickens provide valuable information for evaluation of health status which reflects many metabolic alterations of organs and tissues [5]. Biochemical parameters in indigenous chickens and broiler chickens in various regions of the world differ from each other $[4,6,7]$. It is important to investigate the biochemical profile of indigenous and broiler chickens locally for accurate interpretation of health status [8]. Many researchers have evaluated normal biochemical parameters of industrial and commercial hybrid chickens. But, there is a paucity of literature about the base line value of certain biochemical parameter of broiler and indigenous chickens of Assam. Keeping this in view, the present study has been designed solely to elucidate and compare the serum biochemical profile of broiler and indigenous chickens of Assam.

\section{Materials and Methods}

Forty blood samples from apparently healthy, around two months age 20 each broiler (cob 400 strain) and indigenous chickens of Assam weighing between $1.5-2.0 \mathrm{Kg}$ were collected from local butchers thrice to take average for each parameter at the time of slaughter from Guwahati city. Blood samples $(8 \mathrm{ml})$ were collected aseptically at the time of slaughter and $0.5 \mathrm{ml}$ was mixed with sodium fluoride for estimation of blood glucose. Serum was separated from rest of the clotted blood for estimation of different biochemical parameters namely glucose, total protein, albumin, globulin, cholesterol, urea, uric acid and creatinine using standard protocol as described in commercially available kit procured from in vitro Diagnostic Kits manufactured by Span Diagnostic Limited (Autospan Liquid Gold), GIDC, Sachin-394 230 (Surat), Gujarat, India. Data generated from the experiment were analysed statistically using SAS Enterprise Guide (Version 4.2). 


\section{Results and Discussion}

The concentration of different serum constituents (Mean \pm SE) is presented in Table 1 . Broiler chickens had a significantly higher $(\mathrm{P}<0.05)$ glucose content $(253.28 \pm 3.45 \mathrm{mg} / \mathrm{dl})$ than that of indigenous chickens $(210.55 \pm 1.33 \mathrm{mg} / \mathrm{dl})$ which might be due to the consumption of diet rich in grain. However, the mean values for serum glucose was within the normal range as reported earlier $[9,10]$. Total protein concentration in the broiler and indigenous chickens was recorded as $4.36 \pm 0.05 \mathrm{~g} / \mathrm{dl}$ and $5.2 \pm 0.08 \mathrm{~g} / \mathrm{dl}$ respectively. In indigenous chickens, the significant $(\mathrm{P}<0.05)$ increase of serum total protein might be due to estrogeninduced increase of total protein, as all the blood samples of the indigenous chicken were approaching to mature stage [11]. The serum albumin concentration differ significantly $(\mathrm{P}<0.05)$ between indigenous $(2.62 \pm 0.05 \mathrm{~g} / \mathrm{dl})$ and broiler $(2.06 \pm 0.04 \mathrm{~g} / \mathrm{dl})$ chickens. Serum albumin is influenced by breed, age, physiological state, environment and antigen exposure and is highly variable [12]. Serum albumin is also increase when protein intake exceeds the amount required for growth and maintenance [13] and this might be the probable cause of significant increase $(\mathrm{P}<0.05)$ of serum albumin in the indigenous chicken of the present experiment. Serum globulin concentration in the broiler $(2.30 \pm 0.08 \mathrm{~g} / \mathrm{dl})$ was significantly $(\mathrm{P}<0.05)$ lower than indigenous chickens $(2.58 \pm 0.09 \mathrm{~g} /$

Table 1: Serum biochemical profiles of indigenous and broilers chicken.

\begin{tabular}{|c|c|c|c|}
\hline Parameters & Indigenous chickens & Broiler chickens & F Value \\
\hline Glucose (mg/dl) & $210.55 \pm 1.33 a$ & $253.28 \pm 3.45 b$ & $133.17^{*}$ \\
\hline Total Protein (g/dl) & $5.2 \pm 0.08 \mathrm{a}$ & $4.36 \pm 0.05 b$ & $25.24^{*}$ \\
\hline Albumin (g/dl) & $2.62 \pm 0.05 \mathrm{a}$ & $2.06 \pm 0.04 b$ & $66.15^{*}$ \\
\hline Globulin (g/dl) & $2.58 \pm 0.09 a$ & $2.30 \pm 0.08 b$ & $5.05^{*}$ \\
\hline Urea (mg/dl) & $28.02 \pm 1.38 a$ & $35.32 \pm 1.17 \mathrm{~b}$ & $16.19^{*}$ \\
\hline Uric acid (mg/dl) & $7.07 \pm .013 a$ & $4.21 \pm 0.12 b$ & $75.46^{*}$ \\
\hline Cholesterol (mg/dl) & $152.25 \pm 5.39 a$ & $180.91 \pm 6.49 b$ & $21.07^{*}$ \\
\hline Creatinine $(\mathrm{mg} / \mathrm{dl})$ & $0.96 \pm 0.02$ & $1.00 \pm 0.05$ & 0.58 \\
\hline
\end{tabular}

\section{Conclusion}

From the present study, it was concluded that certain parameters like total protein, albumin, globulin and uric acid was significantly $(\mathrm{P}<0.05)$ higher in indigenous chickens of Assam with compare to broiler (cob 400 strain). However, the concentration of glucose, urea and cholesterol was reordered to be significantly $(\mathrm{P}<0.05)$ higher in broiler. Creatinine concentration did not differed significantly between the two groups.

\section{References}

1. Kondaiah N (1995) Meat and meat products as human feed. Indian Farming 45: 31-34

2. Kemp C, Kenny M (2003) Feeding the modern broiler for more. International Hatchery Practice 17: 11-13.

3. Economic Survey of Assam (2016) An official report by Government of Assam, India.

4. Kalita N, Bhakat C (2011) Growth of female kids under different housing and sources of antibody production [14]. The increase level of globulin concentration might confer higher disease resistance capacity of indigenous chicken of Assam with compare to broiler. The urea concentration in indigenous chicken $(28.02 \pm 1.38 \mathrm{mg} /$ dl) was significantly $(\mathrm{P}<0.05)$ lower than broiler $(35.32 \pm 1.17 \mathrm{mg} /$ dl). However, the concentration of serum urea in both the group was within the range [15]. Indigenous chickens had a significantly higher $(\mathrm{P}<0.05)$ uric acid content $(7.07 \pm .013 \mathrm{mg} / \mathrm{dl})$ than that of broiler chickens $(4.21 \pm 0.12 \mathrm{mg} / \mathrm{dl})$. In chickens, uric acid is a major product of the catabolism of nitrogen. Age and diet may influence the concentration of blood uric in birds. Besides, hyperuricemia has been documented during ovulatory activity [16]. All these might act as factors for increased serum uric acid of indigenous chickens in the present study. Cholesterol content in broiler $(180.91 \pm 6.49 \mathrm{mg} /$ dl) was significantly $(\mathrm{P}<0.05)$ higher than indigenous chickens $(152.25 \pm 5.39 \mathrm{md} / \mathrm{dl})$. Our finding was similar to the earlier report [12]. Lower content of cholesterol in indigenous chickens might be due to their high body activity [17]. In the present investigation, serum creatinine concentration did not differ significantly between indigenous $(0.96 \pm 0.02 \mathrm{mg} / \mathrm{dl})$ and broiler $(1.00 \pm 0.05 \mathrm{mg} / \mathrm{dl})$ chickens. Chicken lacks creatine-dehydrating mechanisms and therefore has very low serum levels of creatinine and higher circulating levels of creatine [18]. dl). Globulin level has been used as indicator of immune responses systems. Indian Veterinary Journal 88(7): 59-61.

5. FAO (1997) Special programme for food security. Diversification component. Draft report, Rome.

6. Pampori ZA, Iqbal S (2007) Haematology, Serum Chemistry and Electrocardiographic Evaluation in Native Chicken of Kashmir. International Journal of Poultry Science 6(8): 578-580.

7. Simaraks S (2004) A Study on the Compression Paddle Materials to Reduce Exposure during Mammography. Journal of Science \& Technology 26: 425-430.

8. Pampori ZA, Iqbal S (2007) Haematology, Serum Chemistry and Electrocardiographic Evaluation in Native Chicken of Kashmir. International Journal of Poultry Science 6(8): 578-582.

9. Islam MS, Lucky NS, Islam MR, Ahad A, Das BR, et al. (2004) Haematological Parameters of Fayoumi, Assil and Local Chickens Reared in Sylhet Region in Bangladesh. International Journal of Poultry Science 3(2): 144-147.

10. Coles EH (1986) Veterinary Clinical Pathology. ( $4^{\text {th }}$ edn) Saunders, Philadelphia, Pennsylvania, USA, pp: 17-19. 
11. Dein FJ (1986) Haematology. In: Harrison GI \& Harrison LR (Eds.) Clinical Avian Medicine and Surgery, WB Saunders, Philadelphia, Pennsylvania, USA, pp: 279-291.

12. Simaraks S (2015) The Effect of Table Height on the Thickness of Neck Muscle during Computer Work. Journal of Science \& Technology 27: 425-430.

13. Bell DJ (1991) Non-protein nitrogen and its fractions in plasma and erythrocytes. In: Bell DJ, Freeman BM (Eds.), Physiology and Biochemistry of the Domestic Fowl. Academic Press Inc, London, UK 2: 921-931.

14. Bowes VA, Julian RJ, Stirtzinger T (1989) Comparison of serum biochemical profiles of male broilers with female broilers and White Leghorn chickens. Can J Vet Res 53(1): 7-11.
15. Fattah SAA, El-Sanhoury MH, El-Mednay NM, Azeem FA (2008) Thyroid Activity, Some Blood Constituents, Organs Morphology and Performance of Broiler Chicks Fed Supplemental Organic Acids. International Journal of Poultry Science 7(3): 215-222.

16. Kaneko J, Harvey J, Bruss M (1997) Clinical biochemistry of domestic animals. ( $5^{\text {th }}$ edn) Academic press, New York, pp. 661- 668.

17. Ritchie BW, Harrison H (1994) Avian Medicine: Principles and Applications, Winger's Publishing, Inc, Florida, USA.

18. Almeida JG, Mendes AA, Quinterio RR, Vulcano LC, Ballarin AW, et al. (2006) Use of Radiograph Optical Densitometry to Monitor Bone Quality in Broiler Breeders. Brazilian Journal of Poultry Science 8(1): 31-38. 